\title{
Financial Education for MSMEs: Entrepreneur's Perceptions and Behaviors in Bogotá
}

\author{
Salomé del Pilar López-Peña \\ Corporación Universitaria Minuto de Dios-UNIMINUTO, Bogotá, Colombia \\ splopezp@unal.edu.co
}

Received date:22 October 2019; Accepted date:11 June 2020; Published date: 25 August 2020

Academic Editor: Jose Luis Gonzalez Conzalez

Copyright (C) 2020. Salomé del Pilar López-Peña. Distributed under Creative Commons Attribution 4.0 International CC-BY 4.0

\begin{abstract}
The purpose of the present work was to identify the perceptions and behaviors related to the economic and financial education in Micro, Small and Medium-sized Enterprises (MSMEs). Cross-sectional and mixed research were conducted within a group of MSME administrators from Bogotá, Colombia. For that purpose, a semi-structured interview was conducted with each participant. The results show a perception of a lack of knowledge about economic and financial education. More than fifty percent of the administrators have not received any type of economic or financial education. Nevertheless, some of the administrators seem to have good financial management. Regarding the sources of financing for MSMEs, most participants identify banks as the only external source of financing, despite identifying them as an expensive and high-risk option. More actions are required in favor of the economic and financial education directed to MSMEs to guarantee their permanence in the market in the long term.
\end{abstract}

Keywords: Financial education, economic education, MSMEs, financial behavior

\section{Introduction}

Economic and financial education (EFE) is considered a fundamental aspect of the economic development of countries for its link to banking and finance. MSMEs are considered the representative figure of entrepreneurship and have been conceived as a possibility for personal growing. EFE plays a fundamental role in the development and long-term maintenance of MSMEs.

EFE is identified as one of the pillars of the economic development of the countries and is given a greater importance in developing countries, due to its incidence 
of poverty. Thus, it is considered that "an articulated and well-directed EFE policy facilitates the reduction of poverty and inequality, allows greater effectiveness in financial inclusion and financial consumer protection actions, and contributes to the development of financial systems" (Comisión Intersectorial para la Educación Económica y Financiera, 2017). While low financial inclusion implies delays in the economic growth and development, as well as affecting levels of savings and credit (Cano, et al., 2014).

In Colombia, EFE is assumed as the principle of protection, consumer law, protection practice, special obligation of the entities and as an objective and instrument of State intervention. This shows the importance of qualified information and also its pedagogical component to achieve a lasting impact on the behavior of people, as a basis for the balance of existing relationships between financial consumers and monitored entities, and as a tool to promote the economic growth of countries, as well as the stability and confidence in national economies (Arrubla, 2016). Thereby, EFE has a broad responsibility both with people and society, and with public and private entities.

According to the Comisión Intersectorial para la Educación Económica y Financiera (2017), the population still lacks the minimum financial knowledge and skills required for responsible economic and financial decision-making. For this reason, there is a consensus on the importance of focusing actions and efforts on specific audiences or populations, one of these are the micro-entrepreneurs. The priority for training includes:1) the administration of household resources and the company, 2) the responsible management of loans, 3) the conditions and tools to access financial products, and 4) the management of entrepreneurship (Comisión Intersectorial para la Educación Económica y Financiera, 2017).

A study conducted by the Banca de las Oportunidades of the Superintendencia Financiera de Colombiain 2015, shows that
" $67 \%$ of people and $55 \%$ of microentrepreneurs have at least one financial product. In both segments, the possession of at least one financial product is higher at the highest socioeconomic levels and in the cities" (Banca de las Oportunidades; Superintendencia Financiera de Colombia, 2015). According to Bravo Geney (2018), the lack of EFE of the micro-business owners generates a short-term decisionmaking with a lack of the necessary support to minimize risks and generate value. Taking these aspects into account, an investigation was conducted to study the knowledge that the owners or administrators of some MSMEs have on financial matters, giving priority to the selfperception of knowledge and the financial behavior of these people over the financial system.

\section{Research Design and Methodology}

A cross-sectional and mixed study was conducted to identify the perceptions and behaviors related to the economic and financial education in MSMEs. The selected sample is shaped by 12 managers or business people from a locality in Bogotá, selected by research convenience. Their participation was free, voluntary and anonymous, a procedure that was guaranteed by signing an informed consent. A semi-structured interview was conducted with each participant. For data analysis, quantitative and qualitative data processing tools were used.

The analysis of the information collected contains a characterization of the sample of people and companies, a presentation of the self-perception of knowledge about EFE, an analysis on the management of resources by entrepreneurs and finally an opinion section on the contribution that each of these companies makes to the economic and social development.

\section{Result}

\section{Sample characterization}

Participants have a similar distribution in terms of gender and age. The educational level shows that $58 \%$ of the participants 
have a technical or technological level, 25\% completed primary school and the remaining percentage is for a woman who did not finish high school and a man who had not completed a professional career.

Although all the participants claimed to be administrators, in the development of the interview, the differences between the functions of each one were clear, ranging from the extreme of being a manager, a founder and an administrator of a company, to the extreme of being an administrator of a point of sales because he/she is the only person available there, who fulfills all the work required without implying to have a certain level of knowledge or training.

The companies analyzed are distributed as follows: $83 \%$ of the companies with less than 10 employees; $8.3 \%$ of the companies with between 11 and 50 employees and the remaining $8.3 \%$ correspond to a company that has 62 employees. The time they have been operating in the market contrasts with the expectations of the study, since 7 of the selected companies have been present in the market for more than 8 years, 3 companies between 6 and 8 years in the market and only 2 have less than two years of existence in the market.

The majority of the companies belong to the category of wholesale and retail trade. Concerning the closing due to bankruptcy or seizure, only one of the companies acknowledged having been at risk, two have been in danger of bankruptcy, but not $s$ related to finance. of seizure and nine have not been or claim to not have been at risk of bankruptcy or seizure.

\section{Perception of knowledge about EFE}

To measure the participant's perception of the financial education knowledge, each participant answered how much he/she knew about certain topics by measuring his/her knowledge on a scale of one to ten, where one meant knowing nothing and ten meant having sufficient knowledge. The results show that the aspects which gained more knowledge are marketing with a weighted average of 7.2, followed by administration and taxes with 6.3. The weighted average of individual knowledge perception ranges between 8.1 and 1.6, with an average of 4.8 , showing a wide fluctuation that is explained by the variety of profiles interviewed.

The radial graph [Perception of knowledge of economic and financial issues (general average)] shows that the other terms used to measure the perception of economic and financial knowledge have a similar distribution, as follows: personal finance, accounting, business finance, economics and legal aspects. It is striking that the perception of knowledge related to business finance, which could be high, given the positions interviewed, has one of the lowest scores, which may indicate that a good part of the people who manage MSMEs do not know or do not believe they have enough knowledge to run a busines 


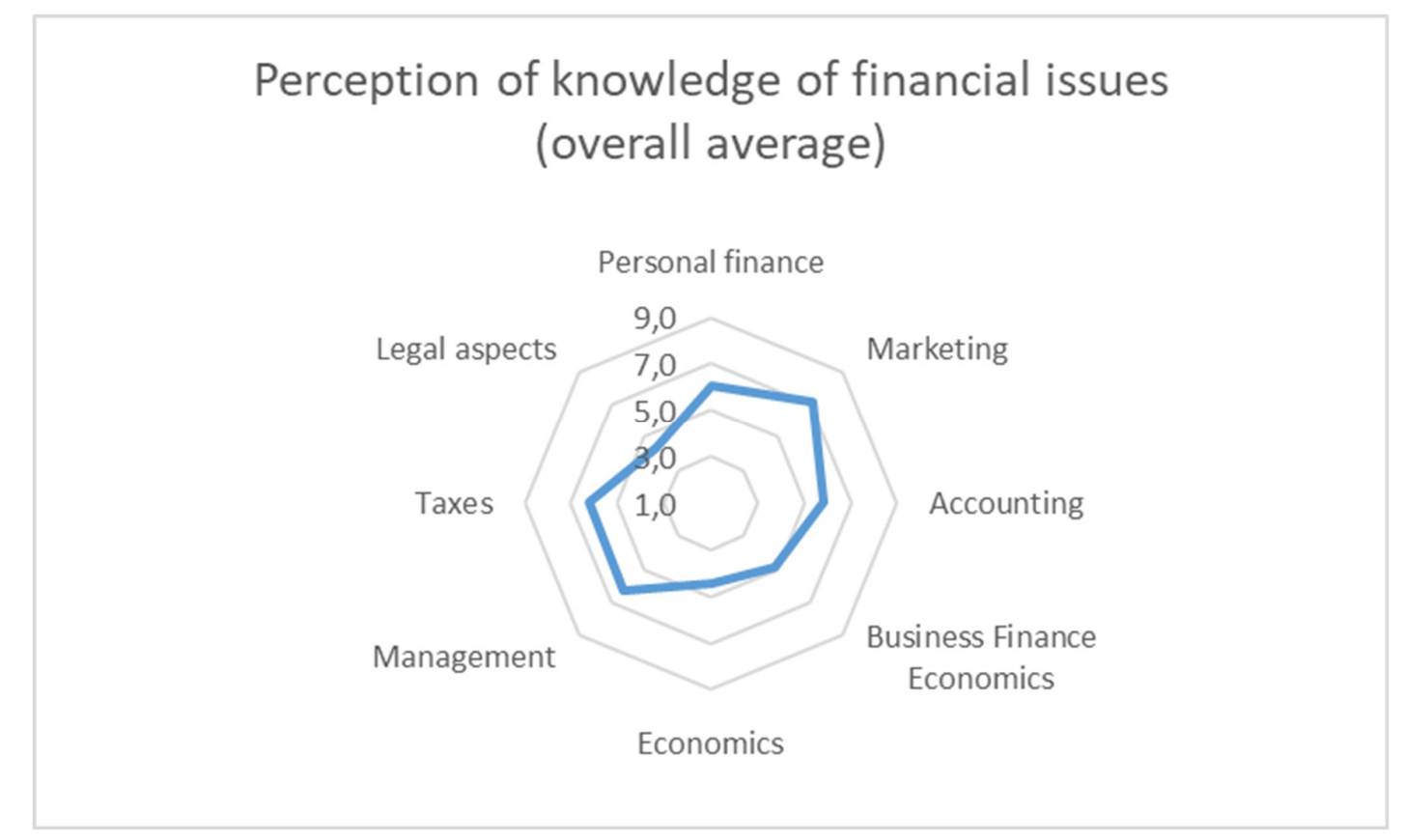

Fig. 1: Perception of knowledge of financial issues (overall average)

Against this background, participants were asked if they had ever received at least one training program on EFE and if they considered it necessary to implement an EFE program for the company's workers. Almost all the entrepreneurs consider the implementation of a training process in EFE necessary, and of these, only 4 have received related training programs.

In these cases, those who have provided the training are from Higher Education Institutions (3), state entities (2), and family members (1). Those who don't consider EEF training necessary, justify it mentioning that due to the functions performed by their employees, they don't require any type of financial knowledge.

$\begin{aligned} & \text { Management of resources by } \\ & \text { entrepreneurs }\end{aligned}$

Funding sources is an essential part of the maintenance and growth of MSMEs. It is the search for the sources of financing that companies do when they require additional funds, regardless of whether or not they have a credit at the time of the interview. It was found that the main source of financing is the banks, a fact that contradicts the aversion showed to the banks, as discussed below. Together, own and family resources almost equal bank resources.

The tree map [Sources of additional resources] shows the distribution of the sources of resources mentioned by the people interviewed, showing that the least mentioned resource in the search tactic is marketing strategies and pressure on employees. One of the businesspersons said that when he needed resources he went to his employees, encouraging them to work more or bring more customers, facing the risk of losing their jobs due to the lack of liquidity of the company. 


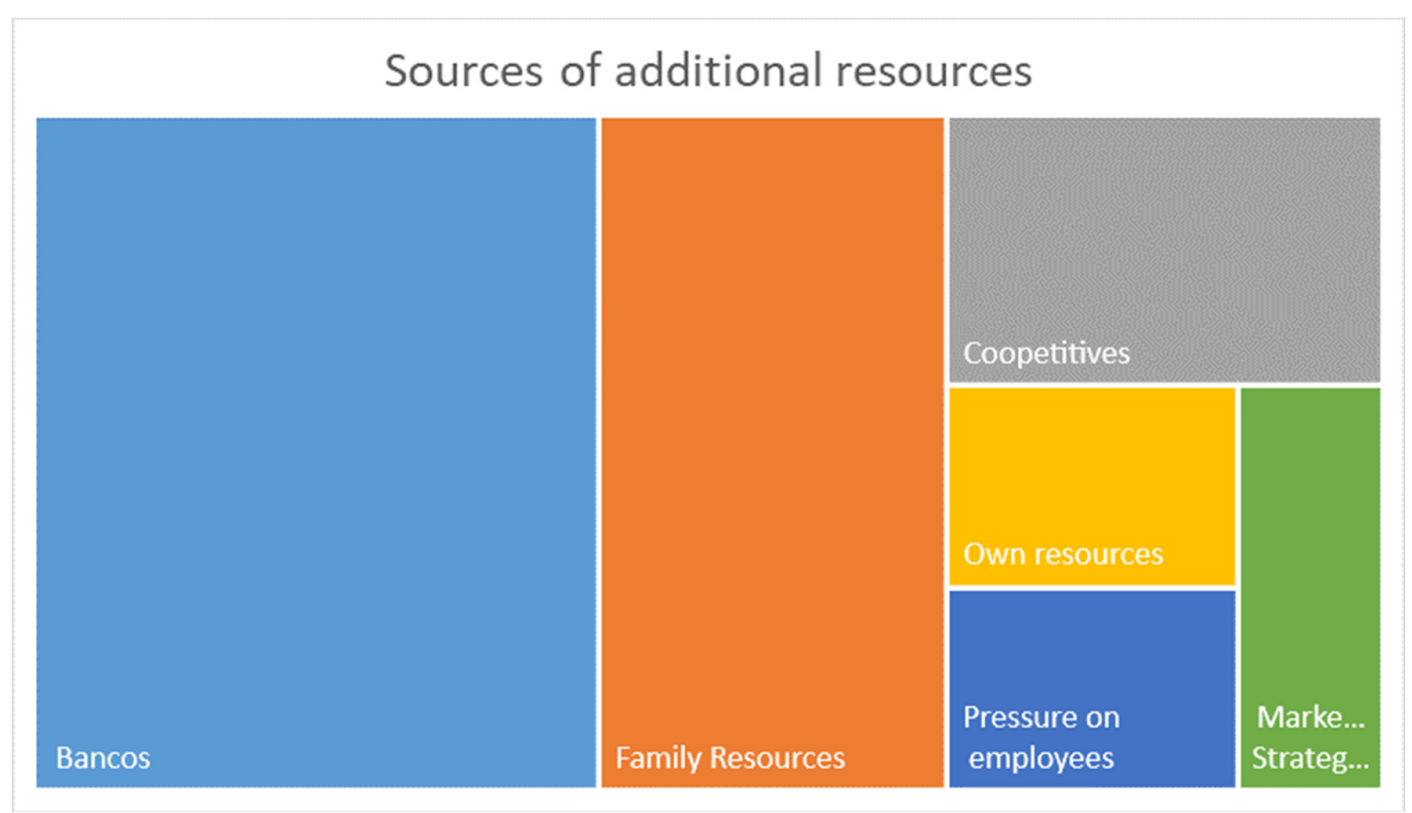

Fig. 2: Sources of additional resources

Regarding the current sources of financing, it was found that banks are the main source of financing followed by cooperatives, which is used by only one of the entrepreneurs. When inquiring about the causes of this unique use of a cooperative, it was discovered that the businessperson had his loans in a financial cooperative that became a bank, the costs increased significantly, so he decided to transfer his financial products to another cooperative with lower costs and a better service.
Participants were asked if they were aware of certain financial products that an MSME could access. $33 \%$ acknowledged not knowing any of the mentioned products. Of the remaining 8 participants, all know about microcredits and business credit cards, while only one businessperson mentioned that he/she knows rediscount credits. The graph [Knowledge of financial products] allows to see the specificity of the answers by financial products. 


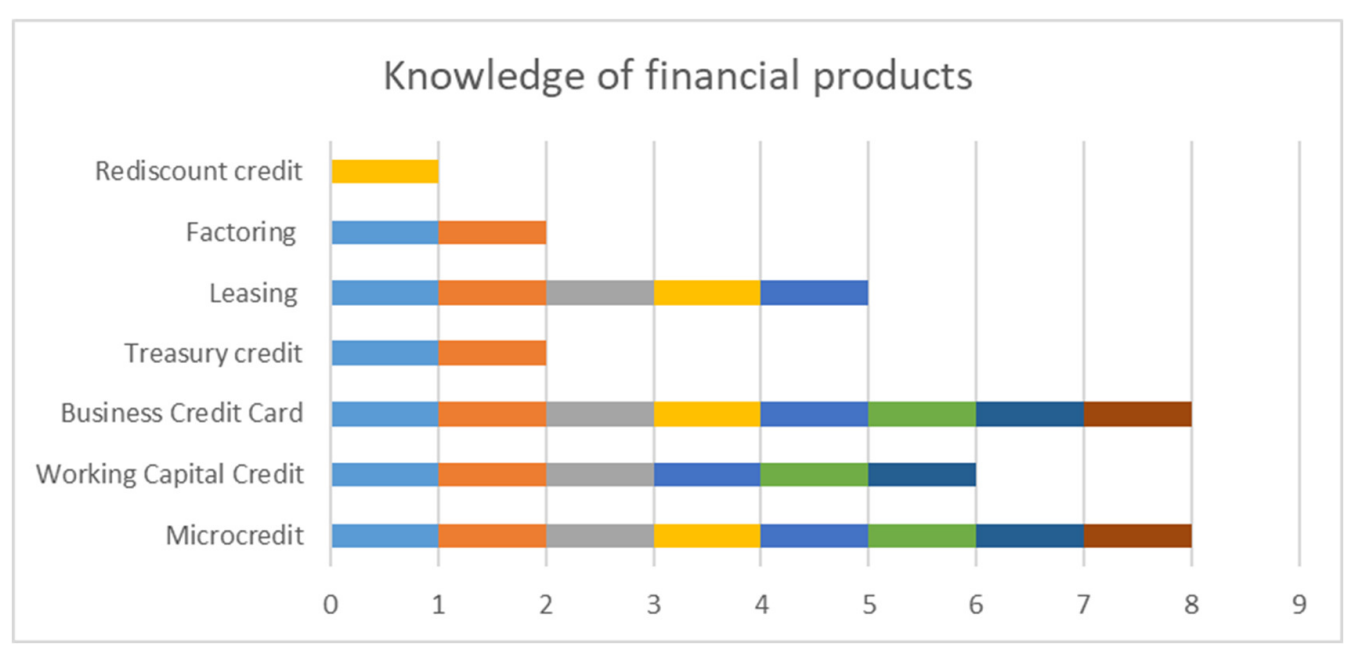

Fig. 3: Knowledge of financial products

Almost all the participants expressed their fear of bank loans, credit cards and banking institutions in general. This fear is justified by the high costs, the ease with which these products can be acquired, the speed with which the money is spent and the difficulties that can arise in paying off the debts acquired.

Of all the companies, half claimed to have a current loan. Of these, $83 \%$ know the term of the credit ( 2 to 5 years), claim to know the additional costs of taking a credit and the benefits of paying in less time than agreed. 50\% know the credit interest rate and $100 \%$ say they are up to date in the obligations related to the loan. Only $50 \%$ of these companies have a professional person specialized in the management of financial resources.

When reviewing the results of all the companies, $92 \%$ have a monthly or weekly budget, know the additional costs of taking a loan and know the benefit of paying a financial responsibility in a shorter-term (if required), and $67 \%$ have a professional person specialized in the management of financial resources. When inquiring about the investments made by the companies, only $25 \%$ of the companies mentioned that they make investments, aimed at modernizing, maintaining or purchasing plant and equipment.

The main barrier that companies find related to financing is the fear of not having resources to pay the acquired financial responsibilities and the fear of the power of the banks, which includes the reports in financial centers and what this means for the future financing of the company. Other barriers mentioned are the high costs of the financial products, the lack of information, the fluctuation of the Colombian economy, changes in the value of the dollar and long periods of recession. $42 \%$ of the participants do not consider having barriers in accessing the financial system, of these, $60 \%$ already have at least one debt with the financial sector.

\section{Contribution to the economic and social development}

Participants were asked if they considered that their companies contributed to the local economic and social development. Only one of the participants considered that he doesn't contribute to the locality. From a list of possible contributions, the entrepreneurs selected the payment of 
taxes and the generation of employment, despite recognizing that taxes for MSMEs are very high and that some of their employees are not Colombian nationals.

One of the businesspersons said that he had decided, given the current national context $^{1}$, to hire only Colombians. Despite considering employment as a significant contribution, only one company pays to its employees more than the current legal minimum wage $\left(\$ 254,7^{2}\right.$ by October 2019). Other companies pay their employees the minimum wage including (or not) social presentations.

Imports, corporate responsibility and the inclusion of persons with disabilities were also selected. Issues such as the purchase of national inputs exclusively and the sale at low prices were mentioned as aspects that contribute to the economic and social growth, for example, through the sales of construction products at low prices for the construction of a park in the town.

\section{Conclusion}

The participants mentioned have the position of administrators; however, their roles, capacities and knowledge vary widely. These consider having more knowledge in marketing, followed by general administration and taxes. The majority of the participants consider it a favorable aspect for the company that its employees receive training programs related to EFE.

Regarding the sources of financing, it was observed that most companies have not been at risk of bankruptcy or seizure, and half of them currently have a loan and they are up to date with the related additional costs. Most companies have a monthly or

\footnotetext{
${ }^{1}$ An increase in the migration of Venezuelan citizens to Colombia has been reported. See for example (EL TIEMPO Casa Editorial, 2017)

${ }^{2}$ Own calculations of average TRM for the year 2019 based on data from (Ministerio de Tecnologías de la Información y las Comunicaciones, 2019)
}

weekly budget and $67 \%$ have at least one professional specialized in the management of financial resources.

It is observed that few companies know other ways of financing instead of banks, such as cooperatives and other entities of the solidarity sector that can boost companies in different ways; not only through granting loans at a lower cost than those of the banks but also providing training, support and financial education that could allow MSMEs to manage their resources more adequately.

Most companies consider that their contribution in terms of paying taxes and generating employment opportunities is significant for the development of the locality. The position of the companies is questionable since, in most cases, they generate unqualified employment without possibilities of social ascent through study or economic ascent through high wages. However, this does not mean that, unlike other companies, MSMEs do generate job opportunities, which can be maintained over time as long as the company exists.

The results found from a small sample of companies can be validated with other companies and locations. The results may vary according to the people and companies selected beyond the position they hold or the type of companies selected, the particular conditions of each company, and the macroeconomic conditions that exceed the control capacity of each one of these.

\section{Acknowledgements}

To Corporación Universitaria Minuto de Dios - UNIMINUTO who financed the research project "Measuring indicators of financial education as part of the socioeconomic development of SMEs in the town of Antonio Nariño in the city of Bogotá" from which this article is derived. To the MSMEs actively participated in the research. To the author's family and friends, for their unconditional support. 


\section{References}

- Arrubla, M., 2016. Finanzas y educación financiera en las empresas familiares Pymes. Sinapsis, Issue 8, pp. 99-118.

- Banca de las Oportunidades; Superintendencia Financiera de Colombia, 2015. Informe de resultados Estudio de inclusión financiera en Colombia: Estudio de demanda para analizar la inclusión financiera en Colombia, Bogotá: s.n.

- Bravo Geney, J. A., 2018. Educación financiera en la generación de valor de las empresas. I+D Revista de Investigaciones, 13(1), pp. 116-124.

- Cano, C. G. et al., 2014. Inclusión financiera en Colombia.
- Comisión Intersectorial para la Educación Económica y Financiera, 2017. Estrategia Nacional de Educación económica y financiera de Colombia , Bogotá: s.n.

- EL TIEMPO Casa Editorial, 2017. Venezolanos, la migración más grande en la historia de Colombia. EL TIEMPO, Marzo.

- Ministerio de Tecnologías de la Información y las Comunicaciones, 2019. Tasa de Cambio Representativa del Mercado -Historico. [Online] Available at: https://www.datos.gov.co/Econom-ay-Finanzas/Tasa-de-CambioRepresentativa-del-MercadoHistoric/mcec-87by 